This is a pre-publication version of this article. Please do not quote from it; please quote only from the published version. The article is published in the Journal of French Language Studies.

\title{
Does Language Loss Follow a Principled Structural Path? Evidence from Jersey Norman French
}

Professor Mari C. Jones

French Section, Faculty of Modern and Medieval Languages and Peterhouse, University of Cambridge

\section{Introduction}

This study considers five hypotheses about contact-induced change made within the framework of Carol Myers-Scotton's Abstract Level model of linguistic structure and her 4-M model of morpheme classification (see, for example, Myers-Scotton 2002; Myers-Scotton and Jake 2017). It examines a linguistic variety which is undergoing heavy structural and lexical contact, namely Jersey Norman French (Jèrriais to its speakers), the indigenous Norman variety spoken in Jersey, one of the British Channel Islands, which lie off France's Cherbourg Peninsula. ${ }^{i}$ As a consequence of Jersey's steady anglicisation, in particular since the late $19^{\text {th }}$ century, the number of speakers of Jèrriais has declined to the point where intergenerational transmission has ceased (Jones 2001, 2015). Today, Jèrriais is spoken by, at a conservative 
estimate, some 1,000 speakers (i.e. fewer than $1 \%$ of the current population), most of whom are elderly (States of Jersey 2012:8). However, despite the fact that, today, English dominates every linguistic domain of island life, many of the remaining speakers of Jèrriais still use the language on a daily basis even though, for most, it may no longer represent their main everyday language (see $\S 2$ below and cf. Jones 2015). ${ }^{\text {ii }}$

The theoretical framework to be tested relates to the phenomenon of linguistic convergence, as drawn from these two models, which are outlined in $\S \S 1.1$ and 1.2 below. Although both models were originally developed within the specific context of codeswitching, the insights they can offer, respectively, about a) how language production proceeds at the abstract level and b) the nature of morpheme types, make them a helpful paradigm in which to consider other types of language contact. As Myers-Scotton and Jake highlight (2017:347), the 4-M model has already been usefully considered in the context of aphasia, creoles, language attrition and second language learning (cf. among others, Myers-Scotton and Jake 2000b; Wei 2000; Jake 1998). The present study extends the application of this model by examining whether Myers-Scotton's theoretical assumptions about the structural path of language attrition (broadly defined as language loss at the level of the individual) also have relevance for the process of language obsolescence (broadly defined as language loss at the level of the community). It also includes a complementary analysis of the Abstract Level model in this context. Although these models are not universally accepted - not least owing to their reliance on the 
theoretical construct of a Matrix Language (see, for example, Myers-Scotton 1993, 1998, 2002; Myers-Scotton and Jake 2000b, 2017 and cf. Bhat, Choudhury and Bali 2016; Gardner-Chloros 2009; MacSwan 2005; Bentahila and Davies 1998:3) - their clearly-defined structural parameters and widespread use within the field bring the advantage of enabling the data discussed herein to be used for systematic comparison with other case studies (see, for example, Schmitt 2000; Gross 2000; Clyne 2003; Deuchar 2006; Nchore 2010; Rahimi and Dabaghi 2013; Priya 2015).

\subsection{The Abstract Level model}

As Myers-Scotton and Jake state, 'Because the M[atrix] L[anguage] is an abstract construct, it is possible for it to be composed of abstract structure from more than one source variety' (2000b:2). The Abstract Level model thus examines how language production proceeds at the abstract level. It is based on the premise that all lemmas in the mental lexicon include three levels of abstract lexical structure (Myers-Scotton 2002:194; Myers-Scotton and Jake 2017:348-349):

(i) Lexical-conceptual structure (semantic and pragmatic information)

(ii) Morphological realization patterns (surface realizations of grammatical structure)

(iii) Predicate-argument structure (the mapping of thematic structure onto syntactic relations) 


\subsection{The 4-M model}

The 4-M model is based on the theory that four distinct types of morpheme are related to the language production process in different ways and are differentially elected within the abstract levels of this process (Myers-Scotton and Jake 2000b:3). The theory considers, specifically, whether any form of 'hierarchy' may be established in terms of the susceptibility of these different types of morpheme to language contact (Myers-Scotton and Jake 2000a). It should be stressed that the model does not claim that such contact-influenced changes are inevitable but simply that, if any contact influence is indeed present, some morphemes may appear to be more susceptible to change than others. The different morphemes, ordered from what Myers-Scotton claims to be the most to the least susceptible to contact-induced influence, are set out in the 4-M model as follows (cf. Myers-Scotton 2002:74-75):

(i) Content morphemes. These morphemes express a concrete meaning and often form the root of a word

(ii) Early system morphemes. These morphemes appear in the same surface-level maximal projections as their heads and depend on them for information about their forms

(iii) 'Bridge' late system morphemes. These morphemes connect content morphemes to each other without reference to the properties of a head, thereby adding information by integrating elements or structures

(iv) 'Outsider' late system morphemes. These morphemes depend for their 
form on information outside their immediate maximal projection. They do not occur in the same constituent as the elements that call them.

It is important to further note that the 4-M model introduces an opposition between [+/- conceptually activated] morphemes (Myers-Scotton 2002:76). Content morphemes and early system morphemes are both [+ conceptually activated] since they are activated by the speaker in order to convey a specific and intentional meaning. They also both appear in the same surface-level maximal projections as their heads. Early system morphemes are closely tied to their content-morpheme heads and depend on them for information about their forms. In other words, they add semantic/pragmatic information to their heads (Myers-Scotton 2002:75). ${ }^{\mathrm{iii}}$ Late system morphemes co-index relationships across maximal projections (Myers-Scotton 2002:78). They are [- conceptually activated] and play a role in building larger syntactic units, since they 'indicate relationships in the mapping of conceptual structure onto phrase structures' (Myers-Scotton 2002:77). The two categories of late system morphemes are distinguished by Myers-Scotton on the basis of the opposition [+/- outside information]. 'Bridge' system morphemes integrate morphemes into larger constituents and indicate the hierarchical relationships that exist between the morphemes that they unite (2002:78), often performing an associative function in a clause or between two clauses (Myers-Scotton and Jake 2017:344). 'Outsider' system morphemes differ from 'bridges' since the information they convey is usually not available until the highest-level 
projection, the Complementizer Phrase (hereafter, CP), is assembled at the level of the Formulator. The Formulator is defined by Myers-Scotton as the level that 'puts together the syntactic strings that follow language-specific well-formedness requirements' (2008:28).

1.3 Application of the models to language loss

From these models, Myers-Scotton develops the following arguments about language attrition:

a) Abstract Level model

'Convergence and attrition result when the three levels of abstract grammatical structure in any lemma in the mental lexicon from language $\mathrm{X}$ are split up and combined with levels in a lemma from language $\mathrm{Y}^{\prime}$ $(2002: 168)$

b) 4-M model

'The extent to which attrition first affects an L1 varies with the type of morpheme' (2002:168).

Each model accounts for particular aspects of structural change in bilingual speech. As seen above, the Abstract Level model provides a mechanism for such change via the splitting of one level of the abstract grammatical structure of one language and its recombination with parts of the same level from 
another language (Myers-Scotton 2002:195). However, while this may account for the distribution of various morpheme-types, it does not explain them. This, then, is the role of the 4-M model.

An interaction is posited within these two models, whereby 'splitting and recombining (the main theoretical notion underling the Abstract Level model) is an earlier attrition feature for conceptually activated morphemes (content morphemes and early system morphemes) than for structurally assigned late system morphemes' (Myers-Scotton 2002:169). The underlying prediction here is that late system morphemes are more resistant to influence from language contact than other types of morpheme.

The specific focus of the present study is to explore whether the five hypotheses developed by Myers-Scotton on the basis of these two models in relation to process of language attrition (2002: Chapter 5) also have relevance for language obsolescence. As can be seen, Hypotheses 1. and 2. depend on the Abstract Level model and Hypotheses 3.-5. relate to the 4-M model.

1. Of the three levels of abstract lexical structure, the level of lexicalconceptual structure in content morphemes is most susceptible to change through attrition/convergence.

2. The level of morphological realization patterns is more likely to show modification in attrition than the level of predicate-argument structure. 
3. Content morphemes are not only 'first in' in language acquisition and in contact situations promoting borrowing, but they are also 'first out' in language attrition.

4. Early system morphemes are less susceptible to replacement or loss in attrition than content morphemes, but more so than late system morphemes. Substitution is more likely than loss.

5. Of all morpheme types, late system morphemes are least susceptible to absolute omission.

To achieve this aim, the analysis will explore a) whether Jèrriais is undergoing contact-influenced language change owing to its abstract grammatical structure being split and recombined with English; and b) whether different morpheme types of Jèrriais are related to the production process in different ways and are, accordingly, more or less susceptible to change during the process of language obsolescence. The analysis also makes available original and hitherto unpublished data on this variety of Insular Norman.

\subsection{Convergence}

As mentioned above, the phenomenon of linguistic convergence (affecting the L1) forms a central part of Myers-Scotton's discussion of linguistic attrition. In this study, therefore, the term 'convergence' is used according to her definition, namely 'a linguistic configuration with all surface morphemes from one language but part of its abstract lexical structure from another language' 
(2002:101). It is further emphasised that, under this definition, 'convergence alone does not involve adding morphemes, but rather only abstract structure' (2002:165). Crucially, and unlike the definition of convergence given by linguists such as Silva-Corvalán (1994) or Hock and Joseph (1996:173), for Myers-Scotton, convergence involves asymmetry in the participation of the languages represented. In other words, it is largely a one-way phenomenon (2002:172). Under this definition, the Matrix Language may become a composite one, being based on an increasing grammatical input from the dominant language. This means that, at a surface level, a CP may be 'bilingual' (i.e. containing material from one or more language). Significantly, however, for Myers-Scotton, the morphosyntactic frame of one language is always maintained so that, although a speaker may potentially change their Matrix Language from one $\mathrm{CP}$ to the next and, thus, switch between monolingual and bilingual clauses, at any given moment, so the hypothesis goes, 'they are speaking only one, even when they resort to the other for assistance' (Haugen 1950:211) (cf. Myers-Scotton and Jake 2017:342).

It should be emphasised that the present study does not suggest that any convergence found to occur in Jèrriais is a predictable nor indeed an inevitable outcome of intensive language contact. Rather, it seeks to explore, via the theoretical models discussed above, whether, in the context of Jèrriais, 'even significant loss has a principled grammar of its own' (Polinsky 1997:401). 


\section{Methodology}

The corpus analysed in this study was compiled from data obtained via free conversation with 66 native (L1) speakers of Jèrriais from different parts of Jersey. The cessation of the intergenerational transmission of Jèrriais (see Jones 2015) means that all speakers were aged over 60 and, for this reason, the present study does not consider age-related variation. All speakers had been completely bilingual in Jèrriais and English since their childhood and, as has been usual practice in Jersey for many decades, had received solely Englishmedium instruction at school. ${ }^{\text {iv }}$ They were of a broadly similar socioeconomic grouping, usually with close connections to agriculture and farming, and were sufficiently proficient in both Jèrriais and English to be able to engage in monolingual discourse in either. As Weinreich (1964:3) and others have noted, language attitudes and proficiency (in each language) can have a bearing on an individual's speech (cf. Jones 2005a). Although this study has attempted to minimize such influence by keeping the sample as homogeneous as possible, it is clearly impossible for such factors to be precluded completely. Owing to Jersey's small physical size (some 5 miles by 9 miles) and to the tight-knit nature of the dwindling Jèrriais speech-community, the speakers interviewed have occasion to interact with each other regularly, both during the course of and outside social events organised by local language planning initiatives (cf. Jones 2000, 2001, 2015: 74-76). ${ }^{\mathrm{v}}$ Indeed, despite the clear overall decline in speaker numbers (cf. Jones 2015), Jèrriais still 
represents an everyday language for all speakers interviewed although, as stated in $§ 1$ above, it may no longer represent their main everyday language. ${ }^{\mathrm{vi}}$

All conversations were conducted by myself and in Jèrriais and, in an attempt to lessen the Observer's Paradox (Labov 1972:32), I was accompanied by a native speaker who was well known to the interviewees and who often took the lead in the conversation. Working with a local research assistant in this way has proved an effective means of facilitating the elicitation of casual speech, especially in cases where the researcher is not a native speaker of the variety being investigated (Milroy and Gordon 2003:75; Bowern 2010:351). Involving a research assistant also makes it easier to tap into several different local social networks and to locate speakers via the friend-of-a-friend sampling method (Milroy 1987), both of which help ensure that the data are broadly representative of the way in which Jèrriais is used within the community of fluent speakers. The effectiveness of these strategies has been demonstrated in previous studies of Jèrriais (see, for example, Jones 2001:4547). As the conversations inevitably varied in length, in an attempt to maintain consistency, 20 minutes of each conversation were analysed for each speaker, making a total corpus length of 22 hours. $^{\text {vii }}$

The study of language change implies a comparison of current and former usage. However, in the case of Jèrriais, no monolingual speakers remain to provide access to monolingual norms, and no comparable corpus of older recordings is available, against which current usage can be measured. ${ }^{\text {viii }}$ In order to provide the present study with a diachronic dimension, therefore, 
where possible, the features discussed are examined in a) the Atlas Linguistique de la France (hereafter, ALF) (Gilliéron and Edmont 1902-10), the data for which were collected in Jersey in 1898, making the work an important source of late nineteenth-century usage; and b) the Atlas Linguistique et Ethnographique Normand (hereafter, ALEN) (Brasseur 1980, 1984, 1997, 2010), whose data were collected in the 1970 s. ${ }^{\text {ix }}$ Information about traditional usage has also been obtained from metalinguistic publications on Jèrriais such as a) Société Jersiaise (2008a and b), which draw on written sources published over the last 200 years and whose content has been checked by trusted native speakers; b) Le Maistre (1966), whose author is acknowledged as having 'une connaissance exceptionnelle et profonde de toutes les choses jersiaises' (Lebarbenchon 1988:191); c) Birt (1985), which was compiled with extensive input from similarly authoritative native speakers, one of whom is described as having 'considerable erudition about all aspects of Jèrriais' (p.4); and d) Spence (1960) and Liddicoat (1994), which draw on data collected via extensive original fieldwork. Where possible, usage has also been examined in the only substantial volumes of prose written by a native speaker of Jèrriais that have been published to date, namely Le Feuvre (1976) and (1983). ${ }^{\mathrm{x}}$ 


\section{Results}

3.1 The Abstract Level model

\subsubsection{Lexical-conceptual structure}

Change in the lexical-conceptual structure of an L1 involves a L1 lexical element being used in what Myers-Scotton terms 'a non-target-like way' (2002:196). In other words, as discussed in $\S 1.3$ above, under the influence of the L2, levels of the abstract structure of the L1 can be split and recombined with levels of the abstract structure of the L2. Thus, for instance, although the surface form of an L1 lexical element may remain unchanged, a new distinction may nonetheless be introduced into that L1 via the element in question being mapped onto the semantics of the L2. Three variables are analysed in relation to the lexical-conceptual structure of Jèrriais, namely the prepositions 'with' and 'after' and the strategies used to express affirmation.

(i) Prepositions: 'with'

In Jèrriais, the different meanings of the preposition 'with' (unmarked, instrumental, comitative) are conveyed by three distinct lexical items. Auve [ov], often replaced in contemporary Jèrriais by the French loanword avec (Birt 1985: 165; Jones 2015: 139), is the unmarked form, which also tends to be used when the referent is animate:

P'têt qué d'main, j'éthons eune chance de paler auve not' vaîsîn 
'Perhaps tomorrow we will have an opportunity to speak to our neighbour'

(Birt 1985:166).

When the instrumental function is being conveyed and/or the object is inanimate, atout [atu] is used:

Frappez l'cliou atout chu marté

'Strike the nail with this hammer'

(Birt

1985:166).

The third preposition, acanté [akãte], conveys a comitative meaning:

Lé Juge s'en r'venait acanté nous en Jèrri

'The Judge was coming back with us to Jersey'

(Birt 1985: 166).

Notwithstanding the description of these prepositions in metalinguistic works (von Wartburg 1946 vol. 2, 11:1417; Le Maistre 1966:3; Birt 1985:166; Liddicoat 1994: 282; Société Jersiaise 2008a:25), and their usage in Jèrriais texts (Le Feuvre 1976:41, 1983:102) the lexical-conceptual structure of contemporary Jèrriais seems to be converging with that of English in this context. Although 'instrumental with' and 'comitative with' contexts were 
produced by, respectively, 15 and 53 informants, no evidence at all appears in their speech of the traditional 3-fold formal distinction, with all 542 tokens found of the aforementioned 'with' contexts in the corpus being realised by the unmarked form auvelavec (see examples (1) - (3). ${ }^{\mathrm{xi}}$ In other words, although the surface form of this preposition that speakers are using is not English in origin, when speaking Jèrriais they do seem to be adopting the 'English' strategy whereby all three distinct semantic functions of 'with' are now being realized by the same lexical element (see Table 1) (cf. Dorian 1981:136 on pluralization strategies in East Sutherland Gaelic).

Table 1 Tokens in the corpus of auve/avec

\begin{tabular}{|l|l|l|l|}
\hline Unmarked & Instrumental & Comitative & TOTAL \\
\hline 459 & 16 & 67 & 542 \\
\hline
\end{tabular}

Unmarked usage

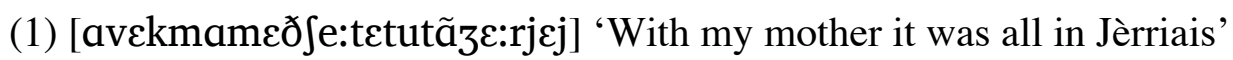

Instrumental usage

(2) [ilãkuvrelamẽtfi:avekdyvrre] 'He used to cover half of it with seaweed' 
Comitative usage

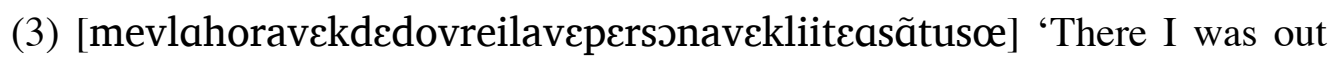
with Dad going to collect seaweed, there was no-one with him, he was on his own'.

(ii) Prepositions: 'after'

In traditional Jèrriais, two prepositions correspond to standard French après 'after', each with a distinct function. Auprès ([ouprei] / [opre]) is the unmarked form:

Auprès aver prîns toute chutte peine-là

'After having taken all that trouble'

(Le Maistre 1966: 31).

A different preposition, souotre, is used for the 'in pursuit of' function (cf. Spence 1960: 222; Le Maistre 1966: 486; Birt 1985:233; Liddicoat 1994:271): $:^{\text {ii }}$

Les deux tchians couothaient souotre not' pétit cat chaque fais qu'i'l'viyaient dans l'gardîn

'The two dogs used to run after our little cat every time they saw him in the garden' 
(Birt 1985: 233).

Table 2. Tokens in the corpus of prepositions used to express 'after' ('in pursuit of') $)^{\text {xiii }}$

\begin{tabular}{|l|l|}
\hline Souotre & Auprès \\
\hline $26(57 \%)$ & $20(43 \%)$ \\
\hline
\end{tabular}

The results in Table 2 demonstrate that, in this context also, English appears to be encroaching on the lexical-conceptual structure of contemporary Jèrriais. The data suggest that the formal opposition that traditionally exists in Jèrriais between the unmarked and 'in pursuit of' meanings is becoming neutralised, with the form auprès being found with the 'in pursuit of' meaning in the speech of 17 of the 32 informants who produced this context. In other words, as seen in examples (4) and (5), the Jèrriais surface form seems to be combining with the semantics of English.

(4) [mãvekwว:rswว:trəji] 'I am going to run after her'

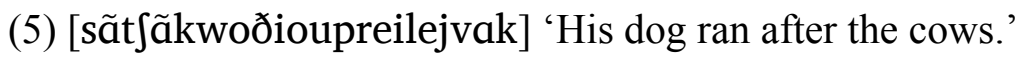

(iii) Affirmation strategies 
Traditionally, Jèrriais uses three different strategies to express affirmation (Le Maistre 1966: 379, 479, 541; Birt 1985:51-52; Société Jersiaise 2008b:353. Véthe confirms a true statement made by an interlocutor, much in the same way as English 'indeed’:

I' fait hardi caûd ch't arlévée - Véthe ('it is very hot this afternoon' - 'Yes' [it is hot])

(Birt

1985:51).

The other forms, oui and si, are used in the same way as in standard French the former being unmarked and the latter used to give an affirmative answer to a negative question:

Sont-i' d'not' avis? - Oui 'Do they agree with us?' - 'Yes'.

Tu n'sors pon ch't arlévée? - Si (fait) 'You're not going out this afternoon [are you?]' - 'Yes [I am]'

(Birt 1985:51-52).

As may be seen from Table 3, in this context also, the English abstract lexical structure appears to be, in part, becoming mapped onto that of contemporary Jèrriais. Although the formal distinction between 'unmarked yes' (oui) and 'contradictory yes' (si) is observed to some extent (see examples (6) and (7)), 
this distinction is no longer categorical in contemporary Jèrriais and 15 different speakers out of the 49 who produced a 'contradictory yes' context, instead generalised the unmarked form to contexts such as (8). ${ }^{\text {xiv }}$

Table 3. Tokens in the corpus of si and oui in 'contradictory yes' contexts

\begin{tabular}{|l|l|}
\hline$S i$ & Oui \\
\hline $38(68 \%)$ & $18(32 \%)$ \\
\hline
\end{tabular}

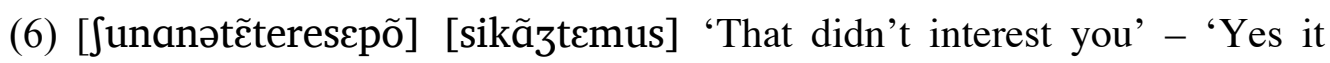
did, when I was a child'

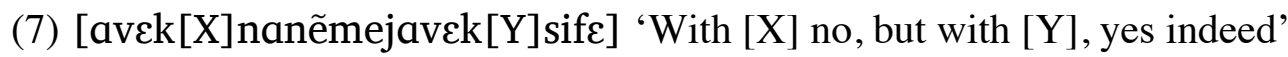

(8) [unepõbẽzanaftœ] [wiulej] 'She's not very young any more' - 'Yes she is.'

(iv) Loan translations

Loan translations, or calques, reflect clearly the way in which the abstract lexical-conceptual structure of Jèrriais may be split and recombined with that of English. The speech of all informants interviewed contained calques. These included word-for-word translations of prepositional verbs (9), (10), (11), (12), of simple prepositions (13), and of idiomatic expressions (14), (15), (16); and also the use of Jèrriais verbs with 'loan shifted' meanings (17), (18) (see 
Appel and Muysken 1993:165; Thomason and Kaufman 1988:76, 90; cf. Jones 2001:123, 127).

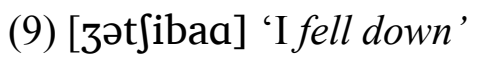

(10) [ Junamgardãnalã] 'That keeps me going'

(11) [3etwo:le:nõ:ba:sje:nu:] 'I've got all the names down at home'

(12) [njapõase:dsu:puraleãtu] 'There's not enough money to go around'

(13) [iljaø̃tadmoaftokinjapõdze:rjeipur] 'There are a lot of words now that there's not any Jèrriais for'

(14) [inpa:lpõlze:rjeisuvãase:] 'He doesn't speak Jèrriais often enough'

(15) [lzoutrlihali:sylagã:b] 'The others pulled his leg'

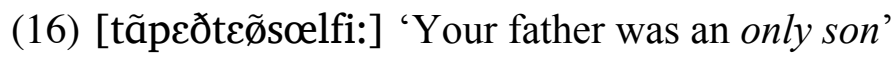

(17) [tsebẽtfikzãtã] 'You know well what I mean'

(18) [dymõ:dkesəmvnyakuneitr] 'People who we have come to know.'

In all the above examples, each individual surface form is unambiguously Jèrriais. However, the precise configuration of these surface forms has created 
structures which diverge from traditional usage and where underlying English syntactic influence is easily identifiable.

\subsubsection{Morphological realization patterns}

Morphological realization patterns represent the way in which grammatical realizations are encoded in the surface structure. In this part of the analysis, three variables are examined quantitatively: the agreement of predicative adjectives, word order and the strategy used to express a repeated verbal action.

(i) Agreement of predicative adjectives

Unlike in English, all Jèrriais nouns have grammatical gender (Birt 1985:14; Liddicoat 1994:231). Adjectives that agree with masculine nouns are unmarked (Birt 1985:30-31, 42-43; Liddicoat 1994:213-216; cf. ALF Maps $135,138,182,916)$

Un garçon heûtheux [õgarsõœ:ðœ:] 'a happy boy'

and those that agree with feminine nouns are marked:

Eune fil'ye heûtheuse [ønfilœ:ðœ:z] 'a happy girl'.

The present study examines gender agreement in predicative adjectives. Since these adjectives are separated from their head-noun by another element, it was 
felt that they provided a good test of the 'strength' of the grammatical relations between them. For an examination of gender-agreement in Jèrriais attributive adjectives, see Jones (2015:125).

Table 4. Tokens in the corpus of predicative adjective agreement with feminine nouns

$\mathrm{F}$ noun $+\mathrm{F}$ adjective $\quad \mathrm{F}$ noun $+\mathrm{M}$ adjective

$353 / 440(80.2 \%) \quad 87 / 440(19.8 \%)$

As demonstrated in Table 4, in most cases speakers select the appropriately marked form of the adjective in the predicative context (see examples (19) to (21)). ${ }^{\mathrm{xv}}$ Nonetheless, the unmarked form of the adjective was recorded with a feminine noun at least once in the speech of 53 informants (see examples (22) to (24)). Since the speech of these informants also contains examples of feminine adjectives being used to quality feminine nouns and since, in any case, gender is encoded elsewhere in the Jèrriais surface structure (e.g. in the singular determiner) these data do not in and of themselves point to the fact that gender agreement is disappearing from the language. Rather, they appear to be indicative of a convergence of Jèrriais and English morphological realization patterns in this context. 
Traditional usage

(19) [ulejhortulalejsitu] 'She's [f.] left [f.] Jersey (lit. 'She's [f.] out [f.]').

She's left everything, ${ }^{\text {xvi }}$

(20) [ulejsikõtãtlabwonfam] 'She's [f.] so happy [f.], that woman'

(21) [usscbskõtãtasaveklapuleavekləko] 'She [f.] would be very happy [f.] to know that the hen is with the cockerel.'

Non-traditional usage

(22) [ $\int$ ejpytodãlazenerasjõkevjer] 'It's rather in the generation [f.] that is old $[\mathrm{m} .]^{\text {,xvii }}$

(23) [ãzع:rictujade:pronõsjasjõokisõdiferã:] 'In Jersey too there are pronunciations [f.] that are different [m.]'

(24) [ulebckõtãkivne] 'She [f.] is very happy [m.] that he was coming.'

(ii) Order of adjective and its head-noun

For Myers-Scotton, 'Abstract specifications for word order at all levels of syntax also represent the level of morphological realization patterns' (2002:202). Accordingly, the data were examined for the ordering of unmarked adjectives and their corresponding head-nouns. In English, 
adjectives are pre-posed whereas in traditional Jèrriais they are generally postposed (cf. ALF Maps 37, 125, 1055A, 1106) - with the exception of a) certain monosyllabic adjectives (cf. ALF Maps 412A, 1176); b) adjectives of colour (cf. ALF Map 568; ALEN Map 380; Birt 1985: 43; Liddicoat 1994:217); and c) a group of common adjectives such as bé 'beautiful', vyi 'old', grand 'big' and p'tit 'small' (cf. ALF Maps 117, 623, 923 among others; Birt 1985:44-45; Liddicoat 1994: 217-218; Jones 2001: 111-112), all of which are traditionally pre-posed. These exceptions, and also all the adjectives listed in Birt (1985:4345) as traditionally pre-posed, were discounted from the analysis.

Table 5. Tokens in the corpus of pre-posed and post-posed adjectives

Pre-posed Post-posed

$253 / 324(78.1 \%) \quad 71 / 324(21.9 \%)$

The results in Table 5 confirm the trend in contemporary Jèrriais towards preposed adjectives, which were present in the speech of all informants except two (neither of whom produced any adjectives) (cf. Jones 2015 and see examples (25) to (28)). Indeed, the adjectives aîsi 'easy', favori 'favourite' and spécial 'special', none of which are listed as pre-posed in Birt (1985), now appear to be exclusively pre-posed in Jèrriais, while natuthel 'natural', triste 'sad' and court 'short', may be both pre-posed and post-posed. Only adjectives of nationality derived from place names and past participles used adjectivally now appear to be post-posed categorically (cf. Birt 1985:44; 
Liddicoat 1994:219, and see Jones 2015:132 for further discussion).

(25) [nətfavəritpjef] 'Our favourite place'

(26) [õmajifikvejzẽ] 'A splendid neighbour'

(27) [ønẽfernelmafin] 'An infernal machine’

(28) [mamaternelgrãmeð] 'My maternal grandmother.'

In fact, in contemporary Jèrriais, the tendency towards pre-position of adjectives appears to be so strong that it extends to qualified and superlative adjectives (see examples (29) to (32)).

(29) [ø̃bẽra:rradjo] 'A very rare wireless'

(30) [øndiversəmãbwวnmejtres] 'An exceptionally good school mistress'

(31) [Jede:hardifarmã:vejzẽ:] 'They are very lovely neighbours'

(32) [ [epõlapy:ptitpa:rejs] 'It's not the smallest parish'

(iii) Strategies used to express a repeated verbal action

Jèrriais traditionally expresses the repetition of a verbal action by means of two different morphosyntactic strategies. The more common is by means of 
the prefix re- which is often metathesised to -èr: r'sétchi 'to dry again'; èrcaûffer 'to heat again' (Spence 1960: 20; Le Maistre 1966: 277, 445 etc; Birt 1985:92-94; Liddicoat 1994:59 cf. Le Feuvre 1976:116 etc). This prefix is found with the same function in standard French (resécher, rechauffer) but the scope of the Jèrriais form is wider since, unlike in standard French, it may also be used with the verbs être 'to be' and aver 'to have': Il r'est malade, l'pouôrre baloque 'he is ill again, the poor old soul'; j'allons r'aver d'la plyie 'we're going to have rain again' (Birt 1985:94). The second, more transparent, strategy is isomorphic with that of English, namely the insertion of the adverb acouo 'again' after the verb: sétchi acouo 'to dry again', caûffer acouo 'to heat again'.

Since both strategies are possible in traditional Jèrriais, the frequent presence in the contemporary language of the more transparent construction cannot be linked definitively to the influence of English, nor can it be considered as a categorical change in the way in which grammatical relations are encoded in the surface structure (cf. Jones 2005b:168-170). The present analysis therefore went a step further, and considered instances where clear evidence was present of a change in the traditional surface structure of Jèrriais. This involved examining a third strategy, not hitherto mentioned in any metalinguistic work on Jèrriais, namely where the repetition of an action is encoded by means of a bi-partite structure, with one 'repetition' morpheme (re-) occurring before the verb and another (acouo) following. The use of this strategy suggests evidence of convergence with English since it appears to 
indicate that the 're- + verb' construction is no longer felt to be transparent enough to convey the notion of repetition without the reinforcement of acouo. 6 speakers made frequent use $(50 \%+)$ of this non-traditional strategy (see examples (33) to (35)) and another 7 produced an overtly hybrid structure in this context by, from time to time, taking the acouo element directly from English (see examples (36) to (38)):

(33) [ilərfi:takwo] 'They did it again'

(34) [epimaka:zakifalelarmetrakwo] 'And then, my coat, I had to put it on again'

(35) [uvulclervejakwo] 'She wanted to see him again'

(36) [ilfõəgen] 'They do it again'

(37) [isõaejpru:vealamneəgen] 'They are trying to bring him again'

(38) [ilasterteəgen] 'He has started again.'

(iv) Verb satellites

English and Jèrriais may differ as to whether or not particular verbs require satellites. Two cases in point are the verbs 'to ask for' (d'mander) and 'to look for' (chèrchi) which, in English, require the satellite 'for' but which, in Jèrriais, do not require a satellite (cf. Le Maistre 1966:171 (d'mander) and Le 
Maistre 1966:100; Société Jersiaise 2008a: 63; ALF Map 22 (chèrchi)) The fact that the satellite pouor is used by 6 speakers out of the 13 who used d'mander (see examples (39) to (42)), and by all 3 speakers who used chèrchi (see examples (43) and (44)) suggests the presence of English-influenced change in the morphological realization patterns of Jèrriais.

(39) [idmãdpurləhernej] 'He asks for the cart'

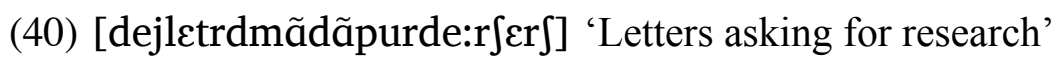

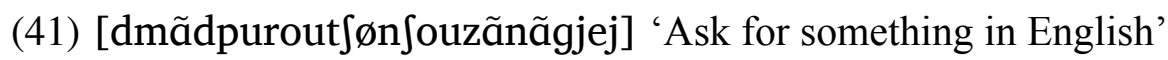

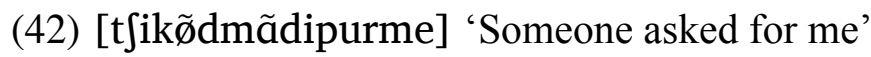

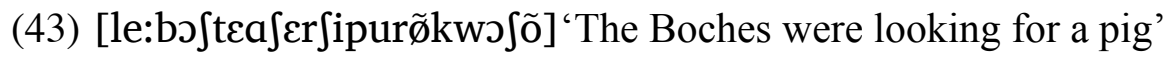

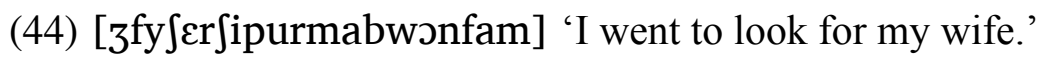

(v) 'Bare infinitive' forms

As will be discussed in $\$ 3.2 .1$, contemporary Jèrriais contains many Englishorigin verb-forms (Spence 1993:24; Jones 2015:146). Since these are usually adapted by means of Jèrriais verbal suffixes: [teste] 'to test', [tit]e] 'to teach', [tIpe] 'to tip', [sprinkli:ne] 'to spring-clean', no resulting change occurs in the patterns of Jèrriais verb morphology. However, the corpus 
contains 8 examples (each from a different speaker) of English-origin verbs occurring as 'bare infinitive' forms in Jèrriais non-finite verb slots without any such morphological adaptation (see examples (45) to (52)). Unlike in MyersScotton and Jake's (2017) discussion of the use of non-finite verbs in a finite verb slot, all examples found in the Jèrriais corpus were in contexts which traditionally trigger an infinitive, suggesting that these Jèrriais 'bare' forms may simply represent unadapted infinitives.

(45) [tyvœrkplektde:foto:] 'You want to collect photos'

(46) [ [unapødistroitavi:] 'That can destroy your life'

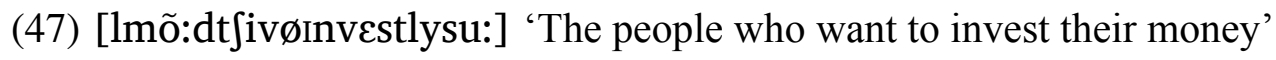

(48) [inpœvpõərestle:zã:] 'They can't arrest people'

(49) [ulejast $\Lambda \mathrm{dI}]$ 'She is studying'

(50) [ilaejpruveainkırıdzle:zã:] 'He tried to encourage people'

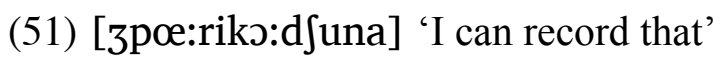

(52) [sulcleraidotfej] 'I used to ride them.'

(vi) Articles that combine with prepositions

Both the Jèrriais masculine singular definite article and the plural definite 
article combine with the prepositions $\grave{a}$ 'to' and dé 'of':

$\grave{A}+l e ́>a u$ 'to the' (singular)

$\grave{A}+l e s>\grave{s}$ 'to the' (plural) (cf. French $a u x$ )

(Spence 1960: 85, 175; Birt 1985: 17; Liddicoat 1994:235; Jones 2015:150 cf. ALF Maps 76, 171, 1245)

$D e ́+l e ́>d u$ 'of the' (singular)

$D e ́+l e s>d e s$ 'of the' (plural)

(Birt 1985: 20 ; Liddicoat 1994: 235; Société Jersiaise 2008a : 97, 110).

These traditional morphological realizations occur in their hundreds in the corpus and are maintained in all but 18 cases: see for example (53) to (55), which were uttered by individuals who otherwise produced traditional forms consistently.

(53) $\grave{A}+l e ́$ (9 tokens) [zedmãdealpy:3œnfreð] 'I asked the youngest brother'

(54) $\grave{A}+$ les (7 tokens) [jade:moukisõdifcrãalenowtr] 'There are some words that are different to ours'

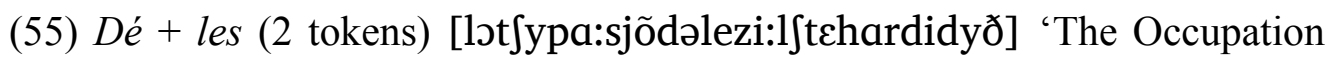


of the Islands was very difficult'.

Although these non-traditional forms are produced without any accompanying hesitation or pause, the fact that they occur so rarely and, each time, in the mouth of a different speaker, suggests that they may represent momentary speech errors rather than evidence of change in progress.

\subsubsection{Predicate-argument structure}

(i) Reflexive verbs

In Jèrriais, certain verbs can be reflexive or non-reflexive in both form and meaning (Birt 1985: 79-82; Liddicoat 1994: 248). An example is laver, which means 'to wash [something]' in its transitive form but 'to wash oneself' in its reflexive form (s'laver) (ALF Map 754 cf. ALF Maps 10, 62, 191, 329, 917). When not being used reflexively, laver can only be transitive: in other words, *il lave (with the meaning 'he washes himself') is an impossible structure in traditional Jèrriais.

As may be seen from Table 6, although most usage in the corpus is consistent with that described in metalinguistic texts, some verbs are, at times, losing their traditional reflexive pronoun.

Table 6 Tokens in the corpus of verbs used with a reflexive meaning

Reflexive pronoun present

$187 / 213$

$(87.8 \%)$
Reflexive pronoun absent

$26 / 213(12.2 \%)$ 
The fact that 16 speakers use non-reflexive forms of 4 different verbs with a clear reflexive meaning (see (56) - (59)), suggests that, for these particular verbs, non-traditional usage may be starting to emerge. Since, in their nonreflexive form, these verbs can traditionally only be transitive, and therefore require an expressed object, this non-traditional usage reflects a change in the predicate-argument structure of Jèrriais, which is likely to be due to convergence with English, a language which does not mark reflexivity as formally as some other Germanic languages (cf. McWhorter 2002). ${ }^{\text {xviii }}$

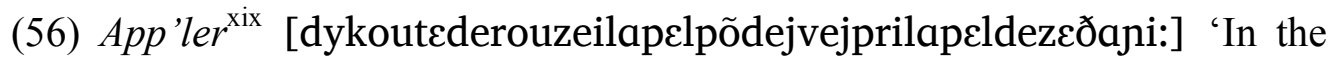
area around Rozel, they are not called vêpres they are called ithangnies'

(57) L'ver ${ }^{\mathrm{xx}}$ [le:filõlve:aø̃kardedzi:] 'The girls got up at a quarter to ten'

(58) Mathier $^{x x i}$ [Jezefã:õmaðje:eilõde:pti:] 'These children have got married and they have children'

(59) Rapp 'ler $^{\text {xxii }}$ [3ərapelzamejlejnõ:] 'I never remember names' 
(ii) Mapping of thematic relations

In traditional Jèrriais, the recipients of the verbs faller 'to be necessary' and mantchi 'to lack, to miss' are encoded in the utterance as indirect objects (cf. ALF Maps 534, 535). This differs from English, where the recipient is expressed as a nominative:

I vous faut mouothi un jour 'You must die one day' (lit. 'it is necessary to you to die one day' (Le Maistre 1966: 235)

Les sou lî manquent 'He is short of money' (lit. 'the money lacks to you') (Le Maistre 1966:337)

Another difference in the mapping of thematic relations between Jèriais and English occurs with the verbs donner 'to give' and rêpondre 'to answer'. In Jèrriais, the experiencer of both these verbs is an indirect object (cf. ALF Map 786), whereas in English it is a direct object:

Jean li a donné les cliés 'Jean gave him the keys' (lit. 'John gave to him the keys')

(Birt 1985:75)

Rêpondre à tchitch 'un 'To answer someone' (lit. 'to answer to someone') (Le Maistre 1966: 450). 
Although traditional usage is usually adhered to in the corpus, the speech of 6 informants contains instances where the mapping of thematic relations has changed - in the case of faller and mantchi, the recipient has changed from indirect object to subject (see examples (60) and (61)) and, with donner and rêpondre, it has changed from indirect to direct object (see examples (62) and (63)). (cf. Table 7, where the number of speakers producing non-traditional usage is given in brackets). Although the number of tokens of non-traditional usage is not high, it is, however, striking that the mapping of thematic relations should change at all (cf. Fuller 2000:54).

Table 7. Tokens in the corpus of the mapping of thematic relations with the verbs faller, mantchi, donner and rêpondre

Traditional usage

Faller (2 speakers)

Mantchi (1 speaker)

Donner (2 speakers)

Rêpondre (1 speaker)
0

24
0

5

Non-

traditional

usage

3

2

1 
(60) [3faledmœðejuktelaferm] 'I had to live where the farm was'

(61) [imãkle:sındeIroust] 'He misses Sunday roasts'

(62) [ø̃livrkezledune] 'A book that I have given him'

(63) [3əlejrepõnyãze:rjej] 'I answered him in Jèrriais'

\subsection{The 4-M model}

\subsubsection{Content morphemes}

For the analysis of content morphemes it was necessary to address the likelihood that the data would contain examples of both single-word intrasentential codeswitches and borrowings (cf. Jones 2001:118-128, 2015: 143-154). Myers-Scotton argues that these lone other-language items occur as part of the same developmental continuum (1993:63) so that, from a synchronic point of view, there is no need, strictly speaking, to distinguish between them (2002:153). Moreover, given that a) the theoretical objective of this part of the study (\$3.2) is to examine the degree of susceptibility to contact shown by different types of morphemes - rather than to undertake a focussed analysis of different types of lone other-language items, and b) all of the forms considered in this section (\$3.2.1) are content morphemes, the precise distinction between codeswitching and borrowing is not central here either. However, rather than risk muddying waters, it has been decided to try - 
as far as possible - to remove lexical borrowings from the current analysis. In the absence of any objective, clear-cut criteria as to how this may be achieved (cf. Poplack and Sankoff 1984, 1988; Poplack, Sankoff and Miller 1988; Poplack and Meechan 1998; Myers-Scotton 1993, 2002; Jones 2005a), this study follows Myers-Scotton (2002:41), Deuchar (2006) and Deuchar, Muysken and Wang (2007) in identifying borrowings on the basis of their predictability and listedness. ${ }^{\text {xiii }}$ Deuchar claims that: '[L]oans are assumed to be listed in the vocabulary of monolingual speakers of the recipient language, whereas switches are not' (2006:1988). Given the absence of any monolingual speakers of Jèrriais (see §2), listedness is defined in this study, following Deuchar (2006), who was also working in a context where no monolingual speakers remain, as words found in either of the most recent dictionaries of Jèrriais, namely Le Maistre (1966) and Société Jersiaise (2008a, b). Words listed in these metalinguistic works were therefore excluded from the analysis.

Contemporary Jèrriais contains many English-origin content morphemes, often as the stems of nouns and verbs. Alongside more wellestablished forms such as dgaîngue (Le Maistre 1966:162, Société Jersiaise 2008a:99) and stèrter (Le Maistre 1966:490; Société Jersiaise 2008a:314) whose listedness, as explained above, has led to them being discounted from the analysis, the speech of all informants contained forms such as (64) to (76)). Although, as discussed in $§ 3.1 .2(v)$, a small minority of English-origin verbs occur in the data as 'bare infinitive' forms (see examples (45) - (52)), most are adapted by means of Jèrriais morphology (see examples (72) to (76)). 
a) English-origin nouns

(64) [falcmetlejreilzsyləlpri] 'The rails had to be put on the lorry'

(65) [ulejtfIldıənzreppurtbmsən] 'She is a children's rep for Thomson [travel company]'

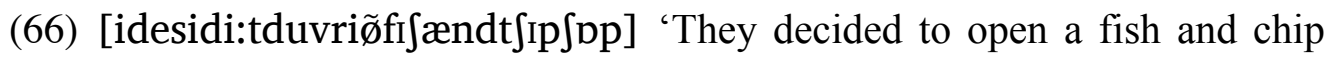
shop'

(67) [mafilaø̃taımJeəoportygal] 'My daughter has a time-share [apartment] in Portugal'

(68) [ $\int$ tedã:lsıvilsœvis] 'I was in the civil service'

(69) [njavepõdəflæts] 'There weren't any flats'

(70) [isõãhplideIaftæ] 'They are on holiday now'

(71) [mejkummafrendsulejdið] 'But as my friend used to say ...'

b) English-origin verbs

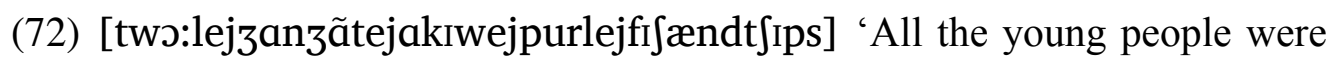
queueing for fish and chips)

(73) [ivnejtestejlywaiəzsje:nu:] 'They came and tested the wires at our 
house'

(74) [ifofəunejamessivre] 'I must telephone Mr Syvret'

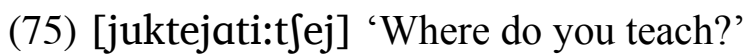

(76) [3əduaIvimãka:] 'I drove my car'

The fact that, in contemporary Jèrriais, most English-origin verbs occur in an adapted form rather than in a 'bare' form suggests that, in this context, even when the content morphemes to which they are bound are contact-forms, Jèrriais system morphemes tend to remain present, and hence appear to be less susceptible than content morphemes to contact-influenced change during language obsolescence (cf. Myers-Scotton and Jake 2017:353). This point will be returned to in $\S 3.2 .2$ (i) below.

The corpus also contains a few examples (such as (77)) of Englishorigin phrasal verbs, where the verb has been adapted but not the adverbial component:

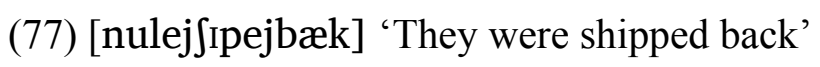

The Jèrriais data therefore confirm Myers-Scotton's Hypothesis 3., namely that content morphemes are highly susceptible to contact-induced change. ${ }^{\text {xiv }}$ 


\subsubsection{Early system morphemes}

Two early system morphemes were analysed, namely plural suffixes and determiners.

(i) Plural suffixes

The $-s$ plural suffix of English (realized as $[\mathrm{s}]$ or $[\mathrm{z}]$ according to phonetic context) is considered by Myers-Scotton and Jake as an early system morpheme because it adds conceptual information to its head noun (i.e. it makes it plural) (2017:344). In spoken Jèrriais, plurality is not generally marked on the noun, which usually remains invariable, number being instead conveyed elsewhere in the utterance (such as by an accompanying determiner (Birt 1985: 29; Liddicoat 1994:232 cf. ALF Maps 141, 796, 1349)). ${ }^{\mathrm{xxv}}$

The analysis sought to determine whether Jèrriais plural suffixes are susceptible to convergence by examining, first, whether Jèrriais nouns are ever pluralized by English suffixes and, second, whether English nouns tend to be pluralized according to the morphological patterns of English or of Jèrriais: in other words, whether the English early system morphemes appear to be elected along with their respective content morphemes. 
Table 8. Tokens in the corpus of the pluralization of Jèrriais-origin content morphemes

Jèrriais system morpheme (null morpheme) English system morpheme ([s] or $[\mathrm{z}])$

3398 $(100 \%)$ $0(0 \%)$

Table 9. Tokens in the corpus of the pluralization of English-origin content morphemes

Jèrriais system morpheme (null morpheme) English system morpheme ([s] or $[\mathrm{z}])$ $68 / 175$ $(38.9 \%)$ $107 / 175(61.1 \%)$

Not one of the 3398 Jèrriais-origin plural nouns in the corpus is formed using the English-origin plural morpheme (see Table 8). Moreover, along similar lines, when an English-origin content morpheme is present, English plural morphology is also present in almost two-thirds of cases (see Table 9, where tokens of the English system morpheme were obtained from 60 different speakers). This suggests that the English plural marker tends to be accessed along with its head-noun (cf. Fuller 2000:54), confirming Myers-Scotton's claim about the strong link that exists between a content morpheme and the early system morpheme that it elects (2002:301). Although the borrowing of plural morphology is well documented in other situations of language contact 
(for example, Gardani 2008; Sommerfelt 1925:7-10; Thomas 1982:210; 214 Comrie 1981:157; Boretzky and Igla 1999:725; Fischer 1961:243), the Jèrriais results are more akin to those of Fuller (2000:54) for Pennsylvanian German, where German-origin nouns only elected an English-origin plural morpheme in 1.3\% of cases (cf. Schmitt 2000:18 for Russian immigrant children in the USA and Roseano (2014) for Friulian).

A good illustration of the resistance to replacement from English on the part of the Jèrriais plural early system morpheme is represented by the form [le:pəli:smən] (les policemans). In English, the plural morphology of the word policeman (i.e policemen) involves a vowel change (umlaut) ([pəli:smən] - [pəli:smen]). The fact that the plural form [le:pəli:smən] (with a plural definite article but no umlaut) was produced by a speaker who is also fluent in English and who is therefore used to the vowel change in the English plural, suggests that the Jèrriais morphological pattern of zero plural marking on the noun is being applied in this instance.

Speakers also frequently mix 'English' and 'Jèrriais' plural noun morphology on English-origin nouns. That no pattern is discernible here in terms of either the particular lexeme used or the phonetic context is demonstrated by examples (78) and (79), where same speaker produces the same lexeme with different plural morphology during the same utterance: 


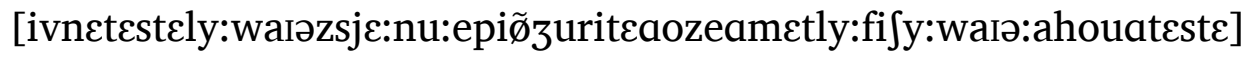

'They came to test their wires at our house and then one day they dared to put their blasted wires upstairs to test them'

(79) [ilãvijede:dæfədrlilãvijese:dæfədılzabrıstəl] 'He sent daffodils, he sent his daffodils to Bristol.'

Moreover, it appears that the plural morphology of English-origin nouns is not always 'fixed' within the Jèrriais speech community. Examples (80) and (81) illustrate how some speakers attach 'English' plural morphology to certain English-origin nouns, whereas other speakers appear to make these nouns plural in accordance with the most widespread pattern for Jèrriais plural morphology, namely a null morpheme:

(80) [isõaferfily:ka:zose] 'They look for their cars in the evening' cf. [ejavede:ka:kivnesylarut] 'And there were cars which came on the road' (81) [alaIstedvıdily:takwoda:seðe:lane:pase:mejsule:mavedejpleız] 'In the Eisteddfod [cultural festival] they still had two evenings last year, but we used to have plays' cf. [zavõfetu:SejpleI] 'We did all those plays.' 
(ii) Definite articles

Definite articles are early system morphemes since they depend upon their head for their form and are conceptually activated (adding specificity to their head) rather than being structurally assigned. In Jèrriais, the definite article can be marked for gender and number (see Birt 1985:15 and Liddicoat 1994: 234 for details). None of the 3,822 definite articles of Jèrriais contained in the corpus is replaced by the corresponding English form (cf. Myers-Scotton and Jake 2017:356), but neither is any omitted altogether, (and this both when the corresponding noun is of Jèrriais origin or of English origin). Once again, this reinforces Myers-Scotton’s claim, mentioned in \$3.2.2(i) above, that the link between these early system morphemes and their heads is a strong one and that it is the Matrix Language (Jèrriais in this case) which has the larger structural role (see examples (82) to (88)).

(82) [ tesyle:krisməska:dz] 'It was on the Christmas cards'

(83) [ilavemẽdãlbeisment] 'He had put it in the basement'

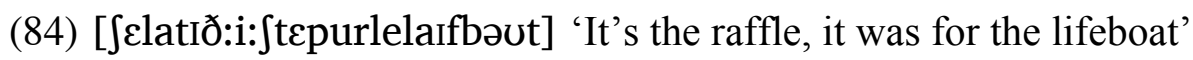

(85) [eləspripkli:ninfalchalele:tapi:ejle:metda:lkjou] 'And the springcleaning, we had to pull out the carpets and put them in the field'

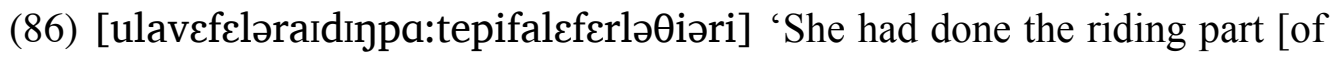


the exam] and then she had to do the theory [part of the exam]'

(87) [zeprẽtufnasylateIp] 'I took all of that on the tape' [i.e. 'I recorded it all']

(88) [zavemãlivdã:lahæmbæg] 'I had my book in the handbag.'

\subsubsection{Late system morphemes}

3.2.3.1 'Bridge' late system morphemes

'Bridge' late system morphemes join together two units - either within a clause or by joining together two clauses (Myers-Scotton and Jake 2017:344). Two types of 'bridge' late system morphemes were examined, namely genitive constructions and associative constructions.

(i) Genitive constructions

In genitive constructions, the Jèrriais 'bridge' late system morphemes $\grave{a}$ 'of', 'to' and déld' 'of' connect the possessor with the item possessed: la fil'ye à John 'John's daughter' [lit. 'the daughter of John'], les dés d'ma main 'my hand's fingers' [lit. 'the fingers of my hand'] (Le Maistre 1966:1; Birt 1985: 17 cf. ALF Maps 246, 356).

As detailed in Table 10 and illustrated in examples (89) and (90), 'bridge' late system morphemes were only found to be replacing their English equivalent (genitive 's) in an extremely small number of instances (although 
each of these instances was obtained from a different speaker):

Table 10. Tokens in the corpus of genitive constructions

Jèrriais 'bridge' morphemes $\quad$ English 'bridge' morphemes

$322 / 326(98.8 \%) \quad 4 / 326(1.2 \%)$

(89) [ivulevejmesperejzzanfreð] 'He wanted to see Mr Perrée's young brother'

(90) [Sejdzpnzzva] 'It's John's horse'.

(ii) Associative constructions

In Jèrriais, where one noun is associated with another, these may be joined morphosyntactically by the 'bridge' late system morphemes $\grave{a}$ 'of', 'to' and déld' 'of': la canne à lait [lit. the jug for milk'] 'the milk jug', eune vaque à lait [lit. a cow that produces milk'], l'baté à vaituthes [lit. 'the boat for cars'] 'the car ferry', la boête dé peintuthe 'the paint box' (Le Maistre 1966:1, cf. ALF Map 909).

As Table 11 indicates, in this context no Jèrriais 'bridge' late system morphemes were found to be lost or replaced. Indeed, in the corpus, Jèrriais 'bridge' morphemes are retained in associative constructions even where the nouns that are being associated are both English in origin (see examples (91) and (92)): 
Table 11. Tokens in the corpus of associative constructions

Jèrriais 'bridge' morphemes English 'bridge' morphemes / no 'bridge' morpheme

$471 / 471(100 \%) \quad 0 / 471(0 \%)$

(91) [ilejalu:niv3:sitideli:dz] 'He is at Leeds University'

(92) [ulapa:sewitəulcvəlzagreIdeI] 'She passed eight 'O' levels at grade A'

The analysis of Jèrriais 'bridge' late system morphemes therefore provides strong support for Myers-Scotton's Hypotheses 4. and 5. In the present study, these morphemes are less susceptible to replacement or loss than early system morphemes (Hypothesis 4.). Moreover, they do not appear to be susceptible to absolute omission (Hypothesis 5.).

\subsubsection{2 'Outsider' late system morphemes}

Unlike 'bridge' late system morphemes, 'outsider' late system morphemes are 'coindexed with forms outside the head of their maximal projection' (MyersScotton 2002:5). They map relationships among arguments and clause structure (Myers-Scotton and Jake 2017:347). As in Deuchar's study of Welsh-English codeswitching (2006:1998), these morphemes are analysed in Jèrriais via the subject-verb agreement of finite verbs. Although this context provides a large number of 'outsider' late system morphemes, not all clauses 
containing finite verbs were able to be examined since Jèriais verb agreement is not marked in all cases. Accordingly, only instances of finite verb forms which traditionally bear a (spoken) morphological inflection in Jèrriais have been analysed (cf. Birt 1985:250-68 for details).

Table 12. Tokens in the corpus of subject-verb agreement

Traditional agreement Non-traditional agreement

$3185 / 3213(99.1 \%) \quad 28 / 3213(0.9 \%)$

Table 12 demonstrates that, in most cases, usage in the corpus is in line with documented norms (cf. Le Maistre 1966: xxx-xxxiii; Birt 1985: 250-268; Spence 1993: 36-38; Liddicoat 1994: 141-210; ALF Maps 10, 12, 23, 24, 27 , $28,30,84,87,91-103$ etc.). This provides further evidence in support of Myers-Scotton's Hypothesis 4. Moreover, unlike with the 'bridge' late system morphemes discussed in $\$ 3.2 .3 .1$ above, none of the 28 tokens of nontraditional usage, (distributed among the speech of 14 different speakers), reveal any evidence that 'outsider' late system morphemes are being replaced by the corresponding English-origin morpheme. Rather, they involve a $3 \mathrm{SG}$ form replacing the 3PL form of the verb in question (see examples (93) to (96)). ${ }^{\text {xxvi }}$ 
[jatrezuzãtimãdãgjejdpa:letule:sjẽ:kivennəpœ:põlpa:leikõprınmejnpœ: põpa:le]

'There is always a lot of English spoken [i.e. at meetings of the Société Jersiaise] not all those who come can speak it [i.e Jèrriais]. They come but they can't speak [it]' (the traditional 3PL present tense form of the verb pouver 'to be able to' is [pœ:v])

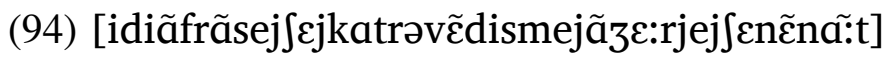

'In French they say it's quatre-vingt-dix ['ninety'] but in Jèrriais it's nénante' (the traditional 3PL present tense form of the verb dithe 'to say' is [di:z])

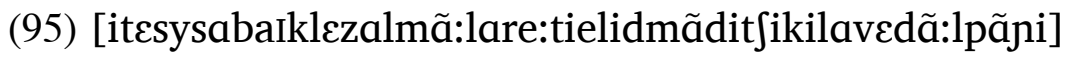

'He was on his bike and the Germans stopped him and they asked him what he had in the basket' (the traditional 3PL preterite tense forms of the verbs arrêter 'to stop' and d'mander 'to ask', are, respectively, [are:ti:t] and [dmãdi:t])

(96) [le:3anpœ:laprãdraftœalejkol] 
'The young people can learn it now at school' (the traditional 3PL present tense form of the verb pouver 'to be able to' is [pœ:v]).

Less frequently, the 3PL morpheme is substituted for the 1PL morpheme (see example (97)). This may indicate influence from English, where the morphological forms of the present tense 1PL and the 3PL are often identical.

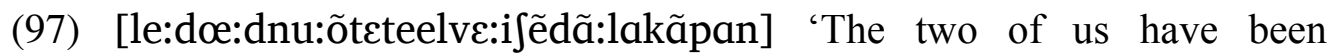
brought up here in the country' (the traditional 1PL present tense form of the verb aver 'to have' is [aṽ̃]).

This analysis of Jèrriais 'outsider' late system morphemes confirms the finding made in relation to 'bridge' outsider morphemes in $\$ 3.2 .3 .1$, namely that, as suggested by Myers-Scotton's Hypothesis 5, in this context of language obsolescence, both types of late system morphemes appear to be extremely resistant to the influence of language contact.

\section{Conclusion}

This case study has demonstrated that, in contemporary Jèrriais, certain nontraditional structural and lexical features have gained currency in the everyday usage of fluent speakers. It is suggested that, since these features are 
reasonably common within the contemporary Jèrriais speech community - as opposed to being found merely in the speech of a few (possibly attrited?) isolated speakers, the five hypotheses that Myers-Scotton develops in relation to her Abstract Level and 4-M models of language production about contactinduced change during language attrition may also have some relevance for language obsolescence.

It has been observed that all three levels of the abstract level structure of contemporary Jèrriais have, to some extent, become split and recombined with parts of the corresponding level of English (§3.1). This results in what might be described, in Myers-Scotton's terms, as a 'converged' linguistic structure, that may bear a Jèrriais surface form but which may also reveal evidence of a more English-origin structure at an underlying level. The Jèrriais data confirm that, of the three levels examined, lexical-conceptual structure, which showed a clear amount of convergence across all variables (§3.1.1), is most susceptible to change (cf. Hypothesis 1). The predicate-argument structure of Jèrriais also revealed convergence to be present in the mouths of some speakers, but this was found to be less widespread across the speechcommunity as a whole $(\S 3.1 .3)$. This level seemed therefore the most resistant to change (cf. Hypothesis 2). Myers-Scotton makes no explicit claim about the relative hierarchy between lexical-conceptual structure and morphological realization patterns, and indeed in the Jèrriais data, these appeared to be quite variable-dependent rather than following any identifiable pattern. For example, in the case of morphological realization patterns, in broad 
quantitative terms at least (see note 13), convergence seemed far more present in the context of predicative adjective agreement (§3.1.2(i)) than with articles that combine with prepositions (§3.1.2(vi)).

Evidence of contact was also observed - to different degrees - in relation to all four of the morpheme-types described in Myers-Scotton's 4-M model. The Jèrriais data confirmed that content morphemes were highly susceptible to contact-induced change (cf. Hypothesis 3), with English-origin items frequent in the mouths of all speakers interviewed (\$3.2.1). Hypothesis 5, namely that of all morpheme types, late system morphemes are least susceptible to omission, was also confirmed by the Jèrriais data, both with regard to 'bridge' late system morphemes (represented in this study by genitive and associative constructions (\$3.2.3.1)) and 'outsider' late system morphemes (represented by subject-verb agreement (§3.2.3.2)). Furthermore, in conformity with the 4-M model as applied in other contexts of language change, both 'bridge' and 'outsider' late system morphemes were found to be resistant to change. However, as Fuller also found in her study of Pennsylvanian German (2000), the isolated instances of these changes meant that it was not possible to establish any precise distinguishing 'ordering' between them.

Of the three hypotheses relating to the 4-M model, Hypothesis 4 proved the least straightforward to substantiate. First, in terms of the relative 'hierarchy' posited between content morphemes: early system morphemes and late system morphemes, although the early system morphemes of Jèrriais were 
clearly less susceptible to change during language obsolescence than its content morphemes, the Jèrriais early system morphemes analysed did not appear manifestly less prone to change than late system morphemes. In the case of the plural suffixes $(\S 3.2 .2(i))$, replacement of a Jèrriais-origin early system morpheme by an English-origin early system morpheme never occurs in the data when the content morpheme to which it is bound is of Jèrriais origin, although it does occur reasonably frequently when the content morpheme in question is also of English origin. In contrast, with the definite articles (§3.2.2(ii)), no instance at all was found of replacement in any context. As discussed, a possible explanation for these findings may be the strong link that exists between a content morpheme and the early system morpheme that it elects (cf. Myers-Scotton 2002:301). Given these findings, the second part of Hypothesis 4 (substitution is more likely than loss) could only be considered in relation to the plural suffixes. However, in this context it was impossible to conclude definitively whether the data were revealing a case of the former or the latter since, in those cases where an English-origin content morpheme does not elect an English early system morpheme (see Table 9), the corresponding Jèrriais-origin system morpheme is in fact realized as a null morpheme.

As Thomason has wisely stated, 'The fact that certain types of contactinduced change are possible in a given contact situation [...] does not mean that we can confidently expect to find them [in all such situations]' (2008:44). However, it is hoped that, by its examination of Jèrriais through the prism of the Abstract Level and 4-M models, this case study of Jèriais has provided 
data that will allow convergence-type changes in language obsolescence to be compared with the same processes in other types of language contact. As a final point, and to answer Polinsky (1997), in the case of Jèrriais significant loss does appear, broadly speaking, to have its own principled grammar. However, the precise linguistic detail of this picture has proven to be somewhat less clear-cut than the statement may suggest.

\section{Bibliography}

Aikhenvald, A. Y. (1996). Areal diffusion in Northwest Amazonia: the case of Tariana. Anthropological Linguistics, 38: 73-116.

Appel, R. and Muysken, P. (1993). Language Contact and Bilingualism. London: Arnold ( $1^{\text {st }}$ edition 1987).

Bentahila, A and Davies, E.E. (1998). Codeswitching: an unequal partnership? In: R. Jacobson (ed.), Codeswitching Worldwide. Berlin: Mouton de Gruyter, pp. 25-51.

Bhat, G., Choudhury, M. and Bali, K. (2016). Grammatical constraints on intra-sentential codeswitching: from theories to working models. arXiv:1612.04538(cs.CL). Available online at: https://arxiv.org/pdf/1612.04538v1.pdf (last accessed 8 February 2018). 
Birt, P. (1985). Lé Jèrriais Pour Tous. A Complete Course on the Jersey Language. Jersey: Le Don Balleine.

Boretzky, N and Igla, B. (1999). Balkanische (südosteuropäische) Einflüsse im Romani. In: U. Hinrichs and U. Büttner (eds), Handbuch der Südosteuropa-Linguistik. Wiesbaden: Otto Harrassowitz, pp. 709-731.

Bowern, C. (2010). Fieldwork in contact situations. In: R. Hickey (ed.), The Handbook of Language Contact. Oxford: Blackwell, pp. 340-358.

Clyne, M. (2003). Dynamics of Language Contact. Cambridge: Cambridge University Press.

Comrie, B. (1981). The Languages of the Soviet Union. Cambridge University Press.

Deuchar, M. (2006). Welsh-English code-switching and the Matrix Language Frame Model. Lingua, 116: 1986-2011.

Deuchar, M., Muysken, P. and Wang, S.L. (2007). Structural variation in codeswitching: towards an empirically-based typology of bilingual speech 
patterns. International Journal of Bilingual Education and Bilingualism, 10/3: 298-340.

Dorian, N.C. (1981). Language Death: The Life Cycle of a Scottish Gaelic Dialect. Philadelphia: University of Pennsylvania Press.

Durand, J., Laks, B. and Lyche, C. (2009). Le projet PFC: une source de données primaires structurées. In: J. Durand, B. Laks and C. Lyche (eds), Phonologie, variation et accents du français. Paris: Hermès, pp. 19-62.

Fischer, W. (1961). Die Sprache der asabischen Sprachinsel in Uzbekistan. Der Islam, 36: 232-263.

Fuller, J.M. (1996). When cultural maintenance means linguistic convergence: Pennsylvania German evidence for the Matrix Language Turnover Hypothesis. Language in Society, 25/4: 493-514.

Fuller, J.M. (1997). Pennsylvania Dutch with a southern touch? A theoretical model of language contact and change. Unpublished $\mathrm{PhD}$ thesis, University of South Carolina.

Fuller, J.M. (2000). Morpheme types in a Matrix Language turnover: the introduction of system morphemes from English into Pennsylvania German. International Journal of Bilingualism, 4/1: 45-58. 
Gardani, F. (2008). Borrowing of Inflectional Morphemes in Language Contact. Frankfurt am Main: Peter Lang.

Gardner-Chloros, P. (2009). Code-switching. Cambridge: Cambridge University Press.

Gilliéron, J. and Edmont, E. (1902-1910). Atlas linguistique de la France. Paris: Honoré Champion (35 volumes).

Gilliéron, J. and Edmont, E. (1920). Atlas linguistique de la France. Suppléments. Volume 1. Paris: Honoré Champion.

Grinevald, C. and Bert, M. (2011). Speakers and communities. In: P. K. Austin and J. Sallabank (eds), The Cambridge Handbook of Endangered Languages. Cambridge: Cambridge University Press, pp. 45-65.

Gross, S. (2000). When two become one: creating a composite grammar in creole formation. International Journal of Bilingualism, 4/1: 59-90.

Haugen, E. (1950). The analysis of linguistic borrowing. Language, 26: 210231.

Hock, H.H. and Joseph, B.D. (1986). Language History, Language Change and Language Relationship. An Introduction to Historical and Comparative Linguistics. Berlin: Mouton de Gruyter. 
Jake, J.L. (1998). Constructing interlanguage: building a composite Matrix Language. Linguistics, 36: 333-382.

Jones, M.C. (2000). The subjunctive in Guernsey Norman French. Journal of French Language Studies, 10/2: 177-203.

Jones, M.C. (2001). Jersey Norman French: A Linguistic Study of an Obsolescent Dialect. Oxford: Blackwell.

Jones, M.C. (2005a). Some structural and social correlates of single word intrasentential codeswitching in Jersey Norman French. Journal of French Language Studies, 15/1: 1-23.

Jones, M.C. (2005b). Transfer and changing linguistic norms in Jersey Norman French. Bilingualism: Language and Cognition, 8/2: 159-175.

Jones, M.C. (2015). Variation and Change in Mainland and Insular Norman: A Study of Superstrate Influence. Leiden: Brill

Kroskrity, P.V. (1993). Language, History and Identity: Ethnolinguistic Studies of the Arizona Tewa. Tucson: University of Arizona Press.

Labov, W. (1972). Sociolinguistic Patterns. Philadelphia: University of Pennsylvania Press.

Lane-Clarke, L. (1978) [1880] Guernsey French. Guernsey: Toucan Press. 
Lebarbenchon, R-J. (1988). La Grève de Lecq. Littératures et cultures populaires de Normandie. Cherbourg: Isoète.

Le Maistre, F. (1966). Dictionnaire Jersiais-Français. Jersey: Le Don Balleine.

Lepelley, R. (1999). La Normandie dialectale. Petite encyclopédie des langages et mots régio- naux de la province de Normandie et des îles anglonormandes. Condé-sur-Noireau: Presses Universitaires de Caen.

Liddicoat, A.J. (1994). A Grammar of the Norman French of the Channel Islands. The Dialects of Jersey and Sark. Berlin/New York: Mouton de Gruyter.

MacSwan, J. (2005). Codeswitching and generative grammar: A critique of the MLF model and some remarks on "modified minimalism". Bilingualism: Language and Cognition, 8/1: 1-22.

Marquis, Y, and Sallabank, J. (2013). Speakers and language revitalization: a case study of Guernésiais (Guernsey). In: M.C. Jones and S. Ogilvie (eds), Keeping Languages Alive. Cambridge: Cambridge University Press, pp. 331- 
354.

McWhorter, J.H. (2002). What happened to English? Diachronica, 19: 217272.

Milroy, L. (1987). Observing and Analysing Natural Language. Oxford: Blackwell.

Milroy, L. and Gordon, M. (2003). Sociolinguistics: Method and Interpretation. Oxford: Blackwell.

Muysken, P. (2000). Bilingual Speech: A Typology of Code-Mixing. Cambridge: Cambridge University Press.

Myers-Scotton, C. (1993). Duelling Languages. Oxford, New York: Oxford University Press.

Myers-Scotton, C. (1998). A way to dusty death: the matrix language turnover hypothesis. In: L. A. Grenoble and L. J. Whaley (eds), Endangered Languages. Cambridge: Cambridge University Press, pp. 289-316.

Myers-Scotton, C. (2002). Contact Linguistics. Oxford: Oxford University Press. 
Myers-Scotton, C. (2008). Language contact: why outsider system morphemes resist transfer. Journal of Language Contact, Thema 2: 21-41.

Myers-Scotton, C. and Jake, J.L. (2000a). Four types of morpheme: evidence from aphasia, codeswitching and second language acquisition. Linguistics, 38: $1053-1100$.

Myers-Scotton, C. and Jake, J.L. (2000b). Testing the 4-M model: an introduction. International Journal of Bilingualism, 4/1:1-8.

Myers-Scotton, C. and Jake, J.L. (2017). Revisiting the 4-M model: codeswitching and morpheme election at the abstract level. International Journal of Bilingualism, 21/3: 340-366.

Nchare, A.L. (2010). The morphosyntax of Camfranglais and the 4-M model. Available online at: ling.auf.net/lingbuzz/001448 (last accessed 8 February 2018).

Polinsky, M. (1997). 'American Russian: Language loss meets language acquisition.' In: W. Browne, E. Dornish, N. Khondrashova and D. Zec (eds), Annual Workshop on Formal approaches to Slavic Languages, pp. 370-406. Available online at: 
https://www.researchgate.net/publication/284410507_American_Russian_Lan guage_loss_meets_language_acquisition (last accessed 8 February 2018). (Cited in Myers-Scotton 2002:185).

Poplack, S. and Meechan, M. (1998). How languages fit together in codemixing. International Journal of Bilingualism, 2:127-138.

Poplack, S. and Sankoff. D. (1984). Borrowing: the synchrony of integration. Linguistics, 22: 99-135.

Poplack, S. and Sankoff, D. (1988). Code-switching. In: U. Ammon, N. Dittmar and K. J. Mattheier (eds), Sociolinguistics. An International Handbook of the Science of Language and Society. Volume 2. Berlin/ New York: Walter de Gruyter, pp. 1174-1180.

Poplack, S., Sankoff, D. and Miller, C. (1988). The social correlates and linguistic processes of lexical borrowing and assimilation. Linguistics, 26: 47104.

Priya, D.P. (2015). Bilingualism: A test of MLF Model. Language in India 15: 135-143. Available online at: http://www.languageinindia.com/dec2015/padmapriyabilingualismfinal.pdf (last accessed 8 February 2018). 
Rahimi, M. and Dabaghi, A. (2013). Persian-English codeswitching: a test of the Matrix Language Frame (MLF) model. System, 41/2: 322-351.

Roseano, P. (2014). Can morphological borrowing be an effect of codeswitching? Evidence from the inflectional morpholology of borrowed nouns in Friulian. Probus, 26/1: 1-57.

Schmitt, E. (2000). Overt and covert codeswitching in immigrant children from Russia. International Journal of Bilingualism, 4/1: 9-28.

Silva-Corvalán, C. (1994). Language Contact and Change: Spanish in Los Angeles. Oxford: Oxford University Press.

Société Jersiaise (2008a). Dictionnaithe Jèrriais-Angliais. Jersey: Le Don Balleine.

Société Jersiaise (2008b). Dictionnaithe Angliais-Jèrriais. Jersey: Le Don Balleine.

Sommerfelt, A. (1925). Un cas de mélange de grammaires. In: Avhandlinger utgitt av Det Norske Videnskaps-Akademi II no.4, Oslo, pp. 3-11. 
Spence, N.C.W. (1957). L'Assibilation de l'r intervocalique dans les parlers jersiais. Revue de Linguistique Romane, 21: 270-288.

Spence N.C.W. (1960). Glossary of Jersey French. Oxford: Blackwell.

Spence, N.C.W. (1993). A Brief History of Jèrriais. Jersey: Le Don Balleine.

States of Jersey (2012). Jersey Annual Social Survey 2012. Available online at:

http://www.gov.je/SiteCollectionDocuments/Government\%20and\%20adminis tration/R\%20JASS2012\%2020121204\%20SU.pdf (last accessed 8 February 2018).

Thomas, A.R. (1982). Change and decay in language. In: D. Crystal (ed.), Linguistic Controversies: Essays in in Linguistic Theory and Practice in Honour of F.R. Palmer. London: Edward Arnold, pp. 209-219.

Thomason, S.G. (2007). Language contact and deliberate change. Journal of Language Contact, 1/1: 41-62. Available online at: http://booksandjournals.brillonline.com/content/journals/10.1163/0000000077 92548387 (last accessed 8 February 2018).

Thomason, S.G. (2008). Social and linguistic factors as predictors of contact- 
induced change. Journal of Language Contact, 2/1:42-56. Available online at: http://booksandjournals.brillonline.com/content/journals/10.1163/0000000087 92525381 (last accessed 8 February 2018).

Thomason, S.G. and Kaufman, T. (1988). Language Contact, Creolization, and Genetic Linguistics. Berkeley, Los Angeles, Oxford: University of California Press.

von Wartburg, W. (1922-). Französiches etymologisches Wörterbuch: eine Darstellung des galloromanischen Sprachschatzes. Tübingen: JCB Mohr.

Wei, L. (2000). Types of morphemes and their implications for second language morpheme acquisition. International Journal of Bilingualism, 4/1: $29-43$.

Weinreich, U. (1953). Languages in Contact. (Reprt. 1964) London: The Hague; Paris: Mouton.

\footnotetext{
i 'Jersey Norman French' is a commonly used term in the literature to denote Jèrriais. Although, strictly speaking, it is something of a misnomer, since
} 
Jèrriais is not a variety of French but, rather a Norman dialect, the term is included here alongside 'Jèrriais' for the sake of consistency and ease of identification.

ii In more advanced stages of language attrition and obsolescence, where evidence of structural convergence exists, the mechanism which sets the stage for such change has been described by Myers-Scotton as a 'turnover' in the 'Matrix Language', (defined as the abstract grammatical frame of a bilingual Complementizer Phrase; see, for example, Myers-Scotton (1998); MyersScotton and Jake (2017)). However, despite its discussion in recent studies of language obsolescence (Fuller 1996a, 1997, 2000), the 'Matrix Language turnover' framework will not be considered here, given Myers-Scotton's important caveat that her claims about this mechanism 'certainly' do not apply in the context of a given speech community's very final fluent speakers (1998:288) and also bearing in mind the caveats expressed about this mechanism by Thomason (2008:45-46), among others.

${ }^{\text {iii }}$ For a different view see, for example, Muysken (2000).

iv Although French served as Jersey's de facto standard language up until the twentieth century, it has always functioned as an exoglossic standard and was never spoken natively by the indigenous population (see Jones 2015:10). The linguistic relationship of Jèrriais speakers with French is therefore akin to that which one would have with a 'foreign' language and, for the most part, it has little relevance to these speakers' daily lives (although the structural similarity 
between French and Norman means that most speakers can understand French reasonably well). For this reason, French is not considered as a possible source of the convergence discussed herein.

v Marquis and Sallabank (2013) note that, for Guernesiais, the fact that speakers are becoming increasingly isolated may bring into question the extent to which it is still meaningful to talk about a 'speaker community' in this context. However, as outlined in $\S 2$, since in Jersey speakers are still able to be located by means of social networks and the 'friend-of-a-friend' technique, the notion of a speech community does not seem, at present at least, to be without relevance for Jèrriais.

${ }^{v i}$ The speech of semi-speakers has not been examined in this study since the well-documented differences in their production skills (cf. Grinevald and Bert 2011) often distinguishes their speech linguistically from that of fluent (L1) native speakers.

vii The importance of maintaining consistency of interview length is emphasized by, for instance, the Phonologie du Français Contemporain project (cf. Durand, Laks and Lyche 2009: 33). Myers-Scotton (1993:204) considers a corpus of 20 hours to be of adequate length for the identification of lone other-language items.

viii The Norman spoken today on the Norman Mainland is not in contact with English. However, given the fact that it, too, is an obsolescent variety and is undergoing a considerable degree of phonological, morphosyntactic and 
lexical influence from French (see Jones 2015) its use as an indicator of prior usage in Jèrriais would not be reliable.

${ }^{\text {ix }}$ Since the ALEN tends to document words in isolation rather than in their syntactic context, the ALF has proved a more useful source of data for the analysis of structural change.

${ }^{x}$ Orthographic forms are cited in the spelling of Le Maistre's Dictionnaire jersiais-français (1966), whose principles are sufficiently close to those of French to enable them to be accessible to the readers of this journal: the main exception being that the digraph th is used to represent the sound [ð], which arises from the assibilation of intervocalic $r$ (cf. Spence 1957). Forms from the ALF and ALEN are transcribed in the IPA rather than in the less widely known phonetic script used in these Atlases. For a comparison of these phonetic alphabets, see Lepelley (1999:56-57).

${ }^{x i}$ Although the Atlas Linguistique de la France (1902-10) contains elicitation phrases for both instrumental with (Maps 345A, 568A) and comitative with (Map 864), a single surface form (either [dov] or [ov]) is recorded in each context here also. This suggests that the convergence discussed in §3.1.1(i) has been under way for over a century.

${ }^{\text {xii }}$ Souotre is attested for Jèrriais in the Supplément to the Atlas Linguistique de la France (Gilliéron and Edmont 1920:273): [ikwoðclœẽswotrelawt] where it is translated as 'à la poursuite de' ('in pursuit of'). A cognate form 
(souventre) is also attested with this function in Guernesiais (Lane-Clarke 1978:7).

xiii In this and the other Tables that form part of the quantitative analysis, the percentages included alongside the raw data are intended as no more than broad indicators of the relative patterns and tendencies observed and should not be considered as precise measurements.

${ }^{\text {xiv }}$ This linguistic feature is not investigated in the ALF or in the ALEN.

${ }^{\mathrm{xv}}$ In the present study, the generalisation of unmarked adjectives in the predicative context is more widespread than in Jones (2015:125), where the use of a masculine adjective to qualify a feminine noun is recorded in only $6 / 78$ cases $(7.7 \%)$. This difference may result from the fact that the present corpus is larger. Moreover, as highlighted in note 13 above, the percentages cited herein should be interpreted as indicating broad trends rather than as exact or absolute measurement.

${ }^{x v i}$ As a point of interest, it is worth highlighting that, in Jèrriais, the adverb hors [hər] has a feminine form horte [hort] which, in traditional usage, appears with feminine nouns (Birt 1985: 96; Spence 1993:38) cf. env'yer sa câsaque horte 'to throw one's coat out' (Le Maistre 1966:295).

${ }^{\text {xvii }}$ In (22), the attributive form of the masculine singular adjective 'old' (vièr [vjer]) is being used in predicative position. The traditional predicative form is vyi ([vi]) (Birt 1985:45; Spence 1993:30). 
xviii cf., for example, the verb 'to shave', which is reflexive in German (sich rasieren) but not in English.

xix (4 tokens - 4 different speakers) (Reflexive: 'to be called'; non-reflexive: 'to call'; Le Maistre 1966:22).

${ }^{\mathrm{xx}}$ (7 tokens -6 different speakers) (Reflexive: 'to get up'; non-reflexive: 'to lift, raise'; Le Maistre 1966:322; Société Jersiaise 2008a:198).

xxi (4 tokens - 3 different speakers) (Reflexive: 'to get married'; non-reflexive: ‘to marry'; Le Maistre 1966:342).

xxii (3 tokens - 3 different speakers) (Reflexive: 'to remember'; non-reflexive: 'to remind', 'to call back'; Le Maistre 1966:443; Société Jersiaise 2008a:277). xxiii I agree with Deuchar that 'listedness' is a somewhat arbitrary criterion and that its adoption in this study may result in some words being mistakenly identified as codeswitches rather than as borrowings since dictionaries 'reflect usage at an earlier point in time rather than the present' (Deuchar 2006:1988). However, in the absence of any clear-cut and universally-accepted criteria to distinguish codeswitches and borrowings, listedness is adopted here owing to the fact that it is acknowledged as a helpful tool in this context by the above and other robust studies of lone other-language items.

xxiv The Jèrriais findings do not imply that Hypothesis 3. necessarily holds good across all cases of language obsolescence. For example, Aikhenvald (1996) discusses how Tariana, spoken in the Vaupes region of Brazilian Amazonia, has been dramatically restructured after the model of the Tucanoan 
languages of the same area almost entirely without lexical borrowing of any kind. Similarly, the Arizona Tewa, though trilingual in Tewa, Spanish and English, show very little lexical influence from the other two languages in their Tewa (Kroskrity 1993) (cf. Thomason 2007 for other examples).

${ }^{x x v}$ Exceptions to this exist, where plurality is marked by a) suppletion [ji] [jer] 'eye - eyes' (cf. ALF Map 932); b) a lengthened vowel: [tru] - [tru:] 'hole - holes' [tfœ] - [tfœr] 'heart - hearts' (Liddicoat 1994: 233) or c) a plural suffix [3va] - [3vo:] 'horse - horses' (Birt 1985:29-30; Liddicoat 1994: 233). In relation to c), personal communication with Jersey's language support officer suggests that ALF Map 269, which records [3va] as both the singular and plural form, may contain a transcription error in the plural. Since this study is not an acoustic phonetic analysis of the kind needed to distinguish vowel length in connected speech, it has not been not possible to examine plural marking via vowel lengthening.

${ }^{x x v i}$ Since no single speaker produced more than 3 non-traditional forms, these data do not appear to be skewed. 